\begin{abstract}
Iranica
Abstracta Iranica Revue bibliographique pour le domaine irano-aryen

Volume 34-35-36 | 2017

Comptes rendus des publications de 2011-2013
\end{abstract}

\title{
Aliye Öztan. Archaeological Investigations at Köşk Höyük, Niğde
}

\section{Astrid Nunn}

\section{(2) OpenEdition}

\section{Journals}

Édition électronique

URL : http://journals.openedition.org/abstractairanica/41544

DOI : 10.4000/abstractairanica.41544

ISSN : 1961-960X

Éditeur :

CNRS (UMR 7528 Mondes iraniens et indiens), Éditions de l'IFRI

Référence électronique

Astrid Nunn, « Aliye Öztan. Archaeological Investigations at Köşk Höyük, Niğde», Abstracta Iranica [En ligne], Volume 34-35-36 | 2017, document 21, mis en ligne le 15 juillet 2016, consulté le 29 septembre 2020. URL : http://journals.openedition.org/abstractairanica/41544 ; DOI : https://doi.org/10.4000/ abstractairanica.41544

Ce document a été généré automatiquement le 29 septembre 2020.

Tous droits réservés 


\title{
Aliye Öztan. Archaeological Investigations at Köşk Höyük, Niğde
}

\author{
Astrid Nunn
}

\section{RÉFÉRENCE}

Aliye Öztan. « Archaeological Investigations at Köşk Höyük, Niğde », in : L. d’Alfonso, M.E. Balza, C. Mora, eds., Geo-Archaeological activities in Southern Cappadocia - Turkey.

Italian University Press, 2010, p. 83-95. (Studia Mediterranea, 22)

1 Köşk Höyük est situé dans le district de Bor dans la province de Niğde. Ce site remonte au néolithique tardif. Après avoir été abandonné au $\mathrm{V}^{\mathrm{e}}$ mill., il fut réoccupé beaucoup plus tard à l'époque achéménide (Late Iron Age Period). Les perturbations dues aux constructions romaines interdisent la reconstitution d'un plan cohérent pour cette phase. Certains tessons de céramique indiquent une importation du monde grec.

\section{AUTEURS}

\section{ASTRID NUNN}

Université de Munich 